\title{
Territorial features of value orientations and satisfaction with the studies of student youth in the Republic of Tatarstan
}

\author{
Ilshat Garafiev, ${ }^{1, *}$, and Gulshat Garafieva ${ }^{1}$ \\ ${ }^{1}$ Kazan National Research Technological University, Karl Marx 68, Kazan, 420015, Russia
}

\begin{abstract}
The paper analyzes the territorial features of value orientations and satisfaction with the studies of student youth in the Republic of Tatarstan. The greatest demand for traditionalist values (family, children, health) was revealed in the city of Almetyevsk, and in Kazan, they are least in demand. The study also showed that in Almetyevsk there is a very low share of the popularity of the value "independence, freedom", and in Kazan, there is a great demand for the value of "money, material wealth", compared to other cities. The data obtained show the influence of the degree of urbanization of the territory on the decrease in the demand for traditionalist values, and the increase in the popularity of modernist and postmodern values. As a reason for dissatisfaction in their studies, the lack of confidence that after graduation they will be able to get a job in their profession was noted by more than a third of students. This indicator is much lower in Nizhnekamsk and in Naberezhnye Chelny, where only every fifth student thinks so, which can be explained by a higher proportion of industrialization of these cities, where many industrial enterprises are concentrated.
\end{abstract}

\section{Introduction}

Sustainable development is understood as a system of organization of society, in which the needs of the current generation are not satisfied at the expense of the possibilities of meeting the needs of future generations. The preservation of natural, human [1-4] and intellectual [5-7] capital, minimization of external effects (externalities) for future generations is considered as the basic principle of sustainable development. With this approach, the key importance is given to the stability of the territory in general, and urban society in particular.

The modern system of higher education is one of the stable social institutions of Russian society, ensuring the socialization of a large proportion of school graduates. The importance of obtaining higher education in Russian society remains quite high, while the requirements imposed on it by various participants in the educational process, first of all, by

\footnotetext{
*Corresponding author: giz05@mail.ru
} 
students, remain high. One of the factors affecting student satisfaction with the educational process is his value orientations.

The purpose of the paper is to identify the territorial features of value orientations and the reason for dissatisfaction with the studies of student youth.

The analysis of the relationship between the values of student youth and various factors is presented in numerous works of Russian and foreign authors. M. Koscielniak, A. Bojanowska considered the impact of values on academically unethical behavior (cheating) of student youth; the authors found that socially oriented human values (conformism and traditions) are negatively associated with unethical behavior, while personality oriented values (hedonism, power and incentives) correlate positively [8].

A. Kałużna-Wielobób studied the relationship between the temporal perspective and values of students. She found a positive correlation between the scale of the future perspective and conformism, traditions, achievements, self-regulation and universalism, and negative - with hedonism; the positive past is positively associated with conformism and traditions [9].

Let us also note the works devoted to the analysis of student satisfaction with the educational process at the university. Most Russian and foreign studies confirm that satisfaction with the educational process directly depends on the work of the faculty personnel. D.A. Kalugina believes that students make rather high demands on the professionalism of the teaching personnel, they want the educational process to be well organized and carried out with the use of new educational technologies [10]. S. Wilkins and M.S. Balakrishnan found that the quality of teaching and the effective use of technology have a significant impact on student satisfaction with higher education in the United Arab Emirates [11]. M. Yusoff, F. McLeay, H. Woodruffe-Burton, among the factors that affect student satisfaction with the educational process, determined the presence of positive relationships with the teaching staff, which should be responsive and professional [12]. N. Martirosyan revealed that the key factors of satisfaction with the educational process for Armenian students are the accessibility, feasibility of the educational program and the quality of teaching [13]. The study by C. M. Ruiz Esteban and J. Santos del Cerro showed that if a teacher clearly explains the subject, makes sure that his explanations are understood, carefully prepares for classes, then the assessment of the quality of teaching will be very high [14].

\section{Methods and types of the Earth's remote sensing}

When analyzing the values of student youth, we took the method of value orientations by M. Rokich as a basis; when designing the questionnaire, the study by N.I. Lapin was used as a benchmark for determining the list of terminal values [15].

We conducted a standardized sociological survey of students of higher educational institutions of the Republic of Tatarstan based on a polymethodical strategy. Differentiation of students in the areas of training is possible: natural and technical, social and humanitarian, and managerial and economic. As a research method, we used a multi-stage combined sample.

Representativeness was determined according to the following characteristics: gender, city of residence and type of student training direction. The sample size was no more than 400 units, depending on the method used. Since we were dealing with a heterogeneous population, the sample size was increased $(n=870)$. The maximum allowable sampling error does not exceed $3 \%$. 


\section{Results and discussion}

Leading positions in the ranking scale are occupied by traditionalist values: family, children $(80.7 \%)$, health $(62.4 \%)$, love $(38.4 \%)$, with the exception of the value of personal safety $(6.0 \%)$. Its low level is largely explained by youthful optimism and carelessness as psychological characteristics of the attitudes of student youth. Then, in pairs, in terms of prevalence, modernist and postmodern values follow. So, a little less than a third of students chose the values: work to their liking (32.2\%), money, material wealth $(32.0 \%)$, more than a quarter of students noted the value of communication with friends $(27.8 \%)$ and career, professional growth $(26,8 \%)$, every fifth student considers success to be valuable for himself $(20.9 \%)$, about one sixth of the respondents chose the values "independence, freedom" (17.8\%) and education, professionalism (15.1\%), respect, recognition (14.8\%).

Table 1. Distribution of respondents' answers to the question "What is most valuable to you in life?" by areas of training and cities of residence in $\%$.

\begin{tabular}{|c|c|c|c|c|c|}
\hline \multirow[t]{2}{*}{ Values } & \multicolumn{4}{|c|}{ Cities } & \multirow[t]{2}{*}{ total } \\
\hline & $\mathrm{NBCH}$ & NZHK & ALM & KZN & \\
\hline family, children & 86.6 & 87.8 & 91.1 & 78.3 & 80.7 \\
\hline health & 68.7 & 65.9 & 86.7 & 59.2 & 62.4 \\
\hline work to your liking & 40.3 & 53.7 & 31.1 & 29.3 & 32.2 \\
\hline money & 27.6 & 29.3 & 24.4 & 33.6 & 32.0 \\
\hline business & 12.7 & & 4.4 & 10.6 & 10.1 \\
\hline success & 23.1 & 7.3 & 15.6 & 21.7 & 20.9 \\
\hline love & 35.8 & 39.0 & 57.8 & 37.6 & 38.4 \\
\hline career & 29.9 & 36.6 & 20.0 & 26.0 & 26.8 \\
\hline communication with friends & 44.0 & 19.5 & 24.4 & 26.7 & 28.9 \\
\hline education, professionalism & 23.9 & 12.2 & 2.2 & 14.3 & 15.1 \\
\hline personal safety & 0.7 & 2.4 & 4.4 & 7.4 & 6.0 \\
\hline prestige, glory & 4.5 & & & 5.9 & 5.1 \\
\hline getting pleasure & 2.2 & 7.3 & 4.4 & 9.4 & 7.9 \\
\hline creation & 6.7 & 22.0 & 8.9 & 10.8 & 10.6 \\
\hline respect, recognition & 12.7 & 29.3 & 8.9 & 14.8 & 14.8 \\
\hline independence, freedom & 26.1 & 22.0 & 6.7 & 16.6 & 17.8 \\
\hline
\end{tabular}

Note: NBCH - Naberezhnye Chelny, NZHK - Nizhnekamsk, ALM - Almetyevsk, KZN - Kazan.

Based on the data in the table, we can say that a significantly higher proportion of demand for traditional values (family, children $(91.1 \%)$, health $(86.7 \%)$, love $(57.8 \%)$, and a very low share of such values as education, professionalism $(2.2 \%)$, independence, freedom $(6.7 \%)$ are among students living in the city of Almetyevsk. This is partly caused by the fact that it is less urbanized, the small town way of life has been preserved there, in which it is unacceptable to demonstrate their uniqueness in relation to others.

For some of the students studying in Nizhnekamsk and Naberezhnye Chelny, a certain set of values has been formed that are much more in demand than in other cities, which show different images of future work. So, in Naberezhnye Chelny, work to your liking is in demand $(40.3 \%)$, on which they value education and professionalism $(23.9 \%)$, understand that the employee is independent, free $(26.1 \%)$ and likes to communicate with friends (44, $0 \%$ ). Such a description of professional activity ideally corresponds to the work model of IT specialists in global corporations such as Google, Apple, Facebook, or in the framework of innovative start-up projects. Thus, in Nizhnekamsk, work to your liking is in demand $(53.7 \%)$, which allows for professional and career growth $(36.6 \%)$, respect, recognition $(29.3 \%)$ and creativity, realization of abilities $(22.0 \%)$. Such a description of professional 
activity ideally corresponds to the model of work within the framework of the Japanese management model, where quality circles, rationalization proposals of ordinary workers play an important role, both horizontal and vertical careers are possible.

For students studying in Kazan, a large city claiming the status of the third city in Russia after Moscow and St. Petersburg, the least demand for traditional values is natural: family, children $(78.3 \%)$, health $(59.2 \%)$, and there is a great demand for the value of "money, material goods" (33.6\%), compared with other cities.

The degree of satisfaction with studies is presented in Table 2.

Table 2. Distribution of respondents' answers to the question "What does not satisfy you in the studies?" by areas of their training and cities of residence in $\%$.

\begin{tabular}{|c|c|c|c|c|c|}
\hline \multirow[t]{2}{*}{ Reasons for dissatisfaction with the studies } & \multicolumn{4}{|c|}{ Cities } & Total \\
\hline & $\begin{array}{l}\text { NBC } \\
\mathrm{H}\end{array}$ & $\begin{array}{l}\mathrm{NZH} \\
\mathrm{K}\end{array}$ & $\begin{array}{l}\mathrm{AL} \\
\mathrm{M}\end{array}$ & $\begin{array}{l}\mathrm{KZ} \\
\mathrm{N}\end{array}$ & \\
\hline predominance of traditional forms of education & 3.7 & 22.0 & 6.7 & 11.6 & 10.6 \\
\hline poor quality of teaching in many disciplines & 9.7 & 24.4 & 8.9 & 19.6 & 17.7 \\
\hline $\begin{array}{l}\text { weak connection of the acquired knowledge with life } \\
\text { and real work in the profession }\end{array}$ & 32.1 & 36.6 & 51.1 & 36.5 & 36.6 \\
\hline $\begin{array}{l}\text { teachers pay little attention to individual work with } \\
\text { students }\end{array}$ & 17.9 & 29.3 & 11.1 & 14.2 & 15.3 \\
\hline often you come across a biased attitude of teachers & 19.4 & 7.3 & 20.0 & 25.0 & 23.0 \\
\hline $\begin{array}{l}\text { I am not sure that after graduation I will be able to get } \\
\text { a job in my profession }\end{array}$ & 23.9 & 19.5 & 40.0 & 39.4 & 36.1 \\
\hline $\begin{array}{l}\text { many shortcomings in the organization of the } \\
\text { educational process }\end{array}$ & 10.4 & 4.9 & 6.7 & 19.7 & 16.9 \\
\hline too much overload, I don't have time & 38.8 & 4.9 & 4.4 & 15.4 & 18.0 \\
\hline everything satisfies & 28.4 & 26.8 & 11.1 & 10.6 & 14.2 \\
\hline
\end{tabular}

Note: NBCH - Naberezhnye Chelny, NZHK - Nizhnekamsk, ALM - Almetyevsk, KZN - Kazan.

First, it should be noted that the share of students who are satisfied with everything in the educational process is about $14.2 \%$, while among those living in Kazan, their share is only $10.6 \%$, in Almetyevsk - $11.1 \%$, more than a quarter of students are satisfied with their studies among those who live in Naberezhnye Chelny (28.4\%) and Nizhnekamsk (26.8\%).

More than a third of respondents named two reasons for dissatisfaction with their studies as selected. Thus, $36.6 \%$ noted a weak connection between the knowledge acquired and life and real work in the profession, and the share of such students in Almetyevsk is much higher $-51.1 \%$. The lack of confidence that after graduating from the university they will be able to get a job in their profession, as a reason for dissatisfaction in their studies, was noted by $36.1 \%$ of students. There is a significant differentiation across the cities. This indicator is much lower in two cities: in Nizhnekamsk - 19.5\%, in Naberezhnye Chelny $23.9 \%$.

The remaining factors of dissatisfaction with the studies can be divided into two groups: the incompetence of the teaching staff and the ineffective performance of the university administration.

The first group of factors includes three reasons for dissatisfaction with the study. The first reason is that you often come across a biased attitude of teachers $(23 \%)$. In terms of share, this reason is most represented among students living in Kazan (25\%), least of all among students living in Nizhnekamsk (7.3\%). The second reason is the low quality of teaching in many disciplines $(17.7 \%)$. There is a significant differentiation across the cities. 
This indicator is much lower in two cities: in Almetyevsk - 8.9\%, in Naberezhnye Chelny $9.7 \%$. It is significantly higher in Nizhnekamsk and equal to $24.4 \%$.

The third reason is the lack of interest among teachers in individual work with students $(15.3 \%)$. In a share ratio, this reason is most represented among students living in Nizhnekamsk (29.3\%), least of all - among students living in Almetyevsk (11.1\%).

The second group of factors includes three reasons for dissatisfaction with the studies. The first reason is that there are many shortcomings in the organization of the educational process $(16.9 \%)$. There is a significant differentiation across the cities. This indicator is much lower in three cities: in Almetyevsk - 6.7\%, in Naberezhnye Chelny - $10.4 \%$, in Nizhnekamsk - 4.9\%. In Kazan, it is higher and equal to $19.7 \%$. The second reason is too much overload (18\%). There is a significant differentiation across the cities. This indicator is much lower in two cities: in Almetyevsk - 4.4\%, in Nizhnekamsk - $4.9 \%$. It is significantly higher in Naberezhnye Chelny $-38.8 \%$.

The third reason is the predominance of traditional forms of education $(10.6 \%)$. In the share ratio across the cities, there is a significant differentiation. This indicator is much lower in two cities: in Almetyevsk - 6.7\%, in Naberezhnye Chelny - 3.7\%. It is in significantly higher Nizhnekamsk $-22.0 \%$.

One of the explanations for such a large differentiation of the last two reasons for dissatisfaction across the cities may be the presence of an inverse relationship between the reasons for too much overload and the use of traditional forms of education, which can be seen in the example of students from Nizhnekamsk and Naberezhnye Chelny.

\section{Conclusions}

As a result of our study, the territorial features of value orientations and satisfaction with the studies of student youth in the Republic of Tatarstan were determined. Their values have a significant impact on various aspects of their life, and the assessment of their satisfaction with their studies at a university is no exception. This certainly must be taken into account when determining the indicators for assessing the quality of the provision of educational services, paying special attention to both the content of the taught disciplines and the clarity of the educational process organization.

The results considered in the paper reflect only part of the data obtained by us from the study conducted. Consideration of the influence of specific values on a certain reason for dissatisfaction with the educational process of student youth is the prospect of our future work.

\section{References}

1. M. Naros, M. Simionescu, Theoretical and Empirical Researches in Urban Management, 14 (2019)

2. F. L. Andrés, Latin American Journal of Economics, 49 (2012)

3. I. Garafiev, L. Gatina, Y. Vafina, WSEAS Transactions on Business and Economics, 16 (2019)

4. J. Kinsler, R. Pavan, Journal of Labor Economics, 33 (2015)

5. L. Feleaga, N. Feleaga, V. Dragomir, L. Rabu, Acta Oeconomica, 63 (2013)

6. G. Garafieva, E. Khvorova, O. Lisina, WSEAS Transactions on Business and Economics, 16 (2019)

7. T. Schoenherr, Transportation Journal, 57 (2018)

8. M. Koscielniak, A. Bojanowska, Front. Psychol, 10 (2019) 
9. A. Kałużna-Wielobób, Annales Universitatis Paedagogicae Cracoviensis. Studia Psychologica, 6 (2013)

10. D. A. Kalugina, The Education and Science Journal, 6 (2013)

11. S. Wilkins, M. S. Balakrishnan, International Journal of Educational Management, 27 (2013)

12. M. Yusoff, F. McLeay, H. Woodruffe-Burton, Quality Assurance in Education, 23 (2015)

13. N. Martirosyan, International Journal of Educational Management, 29 (2015)

14. C. M. Ruiz Esteban, J. Santos del Cerro, Annals of Psychology, 36 (2020)

15. N.I. Lapin, World of Russia. Sociology. Ethnology, 4 (2003) 